\title{
Student Teachers' Storytelling: Countering Neoliberalism in Education
}

\author{
Ola Henricsson, University of Gothenburg, Sweden \\ Email: ola.henricsson@gu.se
}

\begin{abstract}
Everyday teaching involves emotional and relational irrationalities, and these aspects of pedagogical sensitivity and sense are critical for beginning teachers as they develop their practice. The complex elements of what it means to teach are often impossible to grasp from an instrumental approach to teacher education, which emphasizes subject matter knowledge and practical behavioral know-how. Increased educational standardisation and a new teacher training paradigm in Sweden have resulted in positioning future teachers as responsible only for communicating official school knowledge and assessing their learning process. This narrowed understanding of teachers' practice requires another perspective of teaching to be articulated. This article explores the internships of beginning teachers from a phenomenological perspective, drawing on storytelling in teacher education as a way to reveal student teachers' lived experiences. These beginning teachers are learning professional ways of being, which reveal the complexities of teaching, and their accounts have the potential to counter the dominance of neoliberalism in education.
\end{abstract}

Keywords: Teacher Education, Storytelling, Neoliberalism, Phenomenology

\section{Introduction}

Over the past few decades, neoliberal policies have influenced teacher education in Sweden and many Western countries towards a teacher training paradigm that has been closely related to the New Public Management (NPM) educative approach (Apple, 2001; Beach \& Bagley, 2012; Cochran-Smith, 2005; Zeichner, 2010). Nilsson-Lindström and Beach (2015) describe the rise of a new teacher training paradigm in Sweden that emphasizes subject matter knowledge and vocational practical skills: student teachers "are addressed as 'doers' responsible only for communicating official school knowledge and evaluating and assessing pupil performances in relation to it" (p. 253). The ensuing result has been a hollowing-out of the theoretical professional knowledge-base once shared by Swedish teacher educators (Beach \& Bagley, 2012). Deprived of such professional "know-why" knowledge that is based on experience, new teachers may risk entering into the profession unaware of the political and ideological restructuring that is going on all around them: that they, in fact, are the products of a program that focuses on the "construction of a teacher identity for a school that is organized and run as a goal-and results-driven enterprise" (Nilsson-Lindström \& Beach, 2015, p. 248). From a teacher educator's perspective, teaching in Swedish schools has been transformed into an audited, technical, and commodified activity, and this has significant consequences for teachers' in regards to their professional duties and identities (Dovemark \& Holm, 2017; Nordänger \& Lindqvist, 2015). By removing intellectual tools to deconstruct this political and 
ideological restructuring from Swedish teacher education programs, future teachers may risk becoming docile officials who uncritically serve and suffer from the neoliberal agenda (cf. Apple, 2001).

As a teacher educator, I have witnessed the profound impact that neoliberalism has had on teachers' work, and I have struggled to find ways of countering this destructive political force that neglects teaching as a fundamentally in-between human activity that comes with ambiguous, irrational, and emotional dimensions (Koerrenz, 2017). One potential way to resist neoliberalism is through storytelling. I have listened to numerous student teachers' stories of touching moments from their internships, and I have come to realize that their anecdotes have the potential to reveal and acknowledge the ambiguous, emotional, and relational aspects of being and becoming a teacher. Their storytelling, captured as lived experiences, can be used as powerful counter-stories to challenge the instrumentalist view of teaching that results from neoliberalism. Drawing on a phenomenological understanding of storytelling (Young, 1987), the aim of this discussion is to explore storytelling as a way to reveal student teachers' lived experiences (van Manen, 2014) of learning professional ways of being (Dall'Alba, 2009) and recognizing the complexities of teaching (Koerrenz, 2017) that have potential to counter the neoliberal reach into education.

\section{Internship in Swedish Teacher Education}

The most recent reform in Sweden's teacher education field, launched in the wake of a broader neoliberal transformation of the education sector, prompted an increased emphasis on subject matter knowledge and vocational practical skills (Player-Koro, 2012). The Sustainable Teacher Education Commission (STEC) report (SOU, 2008), which paved the way for this regressive move (Nilsson-Lindström \& Beach, 2015), states that teacher education consists of two parts, which has implications for how teacher training should be designed: firstly, subject matter knowledge, which limits teachers' need to understand how a given subject matter affects the condition for learning and, secondly, pedagogical subject knowledge, the knowledge of the social and administrative nature of teaching. In short, teachers "need to be able to manage conflicts, [perform] assessment, [and] evaluation" (p. 382). The STEC report (SOU, 2008) identifies the internship as crucial for student teachers' opportunities to develop this vocational practical "know-how" knowledge, which now constitutes a key component in Swedish teacher education.

In Sweden, there are four internship periods over 20 weeks, and each period is about five weeks in duration. Student teachers are placed in the same school during all periods and are assigned one teacher as their supervisor. The responsibilities for student teachers progress over the internships are: first, they operate in an observation role. With the support of the supervising teacher, they will gradually assume more classroom responsibility in lesson plan development and delivery, which include the application of theoretical knowledge of how pupils learn. The expectation is that these student teachers also incorporate other educational activities frequently assigned to practicing teachers, often understood as school duties. After completing the internship courses, the students should be able to:

- Plan and implement teaching;

- Display relevant subject knowledge;

- Describe and justify didactic choices as well as choice of methods;

- Describe, analyze and assess students' learning in connection with teaching;

- Reflect on leadership and teaching in relation to education act and curriculum;

- Manage educational activities in a flexible way; 
- Act in accordance with the school's values (Gothenburg University, 2018, 2019). ${ }^{1}$

These points reflect significant skills and competences for future teachers in Sweden's schools. Most of these outcomes for beginning teachers, however, are situated within a teacher training paradigm, and none of them explicitly address student teachers' ability to deconstruct the political influences impacting the teaching profession; vis-à-vis the neoliberal reality. The limited role of critical reflection is worrying and frustrating considering that Swedish student teachers regularly encounter schools with supervising teachers influenced by neoliberal undercurrents - there lacks a critical buffer to neoliberal directives. Nordänger and Lindqvist (2015) point out that Swedish primary teachers experience reduced autonomy and tend to develop an individualistic "entrepreneurial identity" that is based on efficiency, accountability, and auditability (p. 216). Building on this point and specific to this discussion, secondary and upper secondary teachers in Sweden described that an increased focus on performance, surveillance, and marketing took attention from core professional duties (Dovemark \& Holm, 2017). Moreover, Lindqvist, Nordänger, and Carlsson (2014) encountered teachers who considered leaving the profession due to the decreased autonomy, growing burden of administration, and excessive documentation. These circumstances fuel the concern expressed by Nilsson-Lindström and Beach (2015): that student teachers in current teacher education programs in Sweden risk forming a teacher identity that perfectly fits into the neoliberal paradigm. This neoliberal dominance forces teacher educators to ask: will this lead to beginning teachers becoming drones to the neoliberal agenda?

I participated in internship seminars where I listened to student-teacher reflections, not as a technical-rational account of their classroom performance as an efficient manager, but where they divulged teaching as a shared relational experience with pupils. Even though most student teachers have experiences that reflect teaching practices deeply immersed in neoliberalism, their stories can also testify to the fact that they have been challenged to act and make judgements in ambiguous and complex pedagogical situations. The anecdotes revealed moments where student teachers have faced complexities and irrationalities that raise many different questions regarding the nature of their future profession, and their embodied experiences of becoming a teacher has evoked various emotions that require understanding. These anecdotes, many of which capture profound experiences from the internship, need to be valued and presented with phenomenological thoughtfulness. Thus, the storytelling sessions allowed us to explore their reflections for pedagogical meaning and, most importantly, these accounts serve as powerful counter-stories that challenge the neoliberal turn in education.

\section{Phenomenological Storytelling}

Becoming a teacher requires a transformation of self, and during their internships, the student teachers involved in this study incorporated set routines and traditions of the school, made scholastic decisions, and acted professionally in accordance to the situated classroom practice, as they were reflecting on their emerging teaching identity. In recent times, this inculturation has been steeped in neoliberalism. With the restricted focus on teacher education, there is little opportunity to guide these beginning teacher reflections in order to make sense of their developing practice. These embodied pedagogical activities that student teachers perform during the internship involve possibilities of realizing self-forming a teacher identity. Dall'Alba (2009) describes how these possibilities unfold in ambiguous fields of tension to include: continuity and change, possibilities and constraints; individual and others; and openness and resistance. Dall'Alba (2009) continues: "when the familiar or everyday appears

\footnotetext{
${ }^{1}$ This list presents the merged learning outcomes for the four periods of internship in the program for primary school teachers at my university. This study focuses on students from this particular education program.
} 
in a new light, the way is open for other possibilities, other ways of being" (p. 37). A phenomenological thoughtfulness is poised to bring an awareness of the lived experience of these different possibilities of becoming and professional ways of being a teacher.

The storytelling in this discussion can capture and reveal student teachers' experiences in their process of learning professional ways of being (Blake \& Blake, 2012; Garvis, 2015; Goodson, 2010; Gustavsson, 2008; Karlsson, 2013; Luehmann, 2007; Yuan \& Lee, 2016). I adopted a small story approach (Bamberg \& Demuth, 2016) and have focused on the everyday stories that were shared by student teachers that showed daily classroom events and pupils' experiences. I refer to these as event narratives (Andrews, Squire, \& Tamboukou, 2008), which can be described as "spoken recounting of particular past events" (p. 8). Ochs and Capps (2001) argue that, when a narrator physically inhabits events of past concern in a story, they reveal themselves authentically, allowing themselves to be animatedly uncovered. The retelling of events often stands out and reveals something, makes something visible, in our otherwise taken-for-granted-ness (Ochs \& Capps, 2001). Furthermore, Ochs and Capps (2001) state: "the past, present and future are sensed holistically" (p. 157) and they propose that narrations of personal anecdotes are a way of illuminating modes of being and becoming. Van Manen (2015) reason that narratives "employ vocabularies that are attuned to the lived meanings" (p. 183) of the life of teaching. Teachers' personal event narratives are, therefore, a way to grasp embodied situated knowledge shown in the very moment of pedagogical action.

Phenomenologically thoughtful storytelling has the potential to contribute to teacher education in Swedish by allowing teacher educators to recognize the complexities involved in student teachers' process of learning professional ways of being. Koerrenz (2017) suggests that the German philosopher Bollnow, who articulated the "significance of emotional, irrational and disruptive aspects of education" (p. 100), makes an important contribution in understanding teachers' being and becoming. Bollnow's philosophy of educational reality help us see the classroom as "a relational place of ethically and emotionally significant action and interaction" (see Koerrenz, 2017, p. 101) and provides a significant counterbalance in a neoliberal era of increasing standardization and instrumentalism.

\section{Interwoven Storytelling}

Oral storytelling, as an interwoven phenomenon of both the story - the student teachers' lived experience descriptions of learning professional ways of being-and the storytelling - revealing the emotional and embodied occasion of story sharing - is examined phenomenologically. From the perspective of becoming a teacher, the everyday storytelling (Ochs \& Capps, 2001) about events that touched them professionally is important. Not only do these stories recount the student teachers' embodied experiences of the complexities in teaching, but the act of telling itself is an embodied and emotional experience. Young (2000) shows that emotions in oral storytelling are not just represented in a story as if the narrator "retrieves emotions from the past" (p. 79) but are occasioned in the embodied act of storytelling and, furthermore, that the body is enlivened by both the past and the present. The body is touched twice and both these embodiments - of the past and in the present-are sites of transformations and becoming that have potential to open up professional ways of being that are neglected in the neoliberal approach to teaching.

Even listening to a story can be an ambiguous experience of "being with yourself," shifting focus to imaginary events, while at the same time being intercorporeal (Merleau-Ponty, 1968) through the storyteller's embodiment. Young (1987) describes the experience of storytelling with the concepts of taleworld and storyrealm: "Taleworlds are realms of events as they are conjured up by storyrealms" (p. 197). Storyrealm is where listeners and tellers experience the storytelling occasion taking place in an intersubjective world of sociality. Participants are aware of themselves as listeners and storytellers. The storyrealm is designed to 
orient the listener to shift focus to another realm of experience, the taleworld. According to Young (1987), when we experience the taleworld, where the actual events that the story recounts unfold, the listener loses her sociality, her engagement with others, and even the sense of felt-time (p. 17). Inside the taleworld, the listener can experience herself as one or several of the characters, or move around as an observer, but it is still in the time and space of the taleworld. This is a different experience than the storyrealm where you experience yourself as a social person in a storytelling occasion. A good deal of what people do when narrating is unconscious, especially with gestures, posture, and facial expressions, and these body expressions are often outside of the storyteller's awareness. This means that stories do not spring from the brain to the tongue and get uttered as mere words. The story inhabits the whole body and the body is the conveyor. Thus storytelling is an embodied activity and the assumption here is that alongside the spoken words are gestures, facial gestures, and body postures of significance for how we experience storytelling as intercorporeal (Merleau-Ponty, 1968; Young, 2011).

Historically and socially, we are situated in time and place, and we use stories and storytelling as a meaning-making tool (Bruner, 1986). A compelling narrative text contains punctum and, as van Manen (2014) argues, punctum has the ability to bring about an understanding that goes beyond a pre-described social and cultural understanding when reading a story. Punctum offers a detail that "claims the power to stir us and to bring about an understanding that ordinary propositional discourse cannot do" (van Manen, 2014, p. 253). It helps the reader to see something and acknowledge something in the ambiguity of a personal lived experience. I will use the concept of punctum when exploring the student teachers' oral storytelling. To grasp the punctum, in hearing each story, I had to try to set aside, or see beyond, my pre-conceived way of understanding and interpret the interwoven story and storytelling.

\section{Storytelling Sessions}

An invitation to participate was sent out to 87 future primary school teachers and 19 agreed to participate in the video recording of their praxis seminar, each comprised of four or five participants. The participants in this inquiry had just completed their first internship during their second semester as a student teacher. They returned to the university at the conclusion of their internship to attend a praxis seminar, where they would discuss different questions and tasks aligned with the aims of the course. As part of the video recorded praxis seminar, they were asked to tell one another a story about an event that was significant for them during their internship. Notably during this first internship, they mostly observed classes taught by their supervising teacher.

The camera was directed towards the chair occupied by the storyteller. I was in the room, behind the camera, and sometimes they turned to the camera, to me, and showed the natural attitude of the storyteller, who addresses everyone who listens and takes them into account. As a participant in the storytelling occasion and from watching the video recording, this allowed me the basis from which I could explore the student teachers' storytelling. I was able to see opportunities as student teachers expressed ambiguous experiences of learning professional ways of being, which revealed the complexity of teaching experiences. The recorded transcriptions were analyzed by initially identifying event narratives in the stream of talk. I then examined how the student teachers created a background where the plot and characters were described and how they then shifted focus to how the events unfolded in time and space. The video recording lasted approximately 40 minutes per group and each anecdote took about four to six minutes to share. In between the stories, the other student teachers talked about similar experiences and asked questions as was naturally expected in response to a story.

A lived experience of teaching shared through oral storytelling comes with a complex, intertwined, ambiguous, and intercorporeal experience, of both body and imagination. 
Without detracting from other kinds of non-verbal communication, such as eye contact, selftouching gestures, and pitch of the voice, I focus in this article on their gestures and body postures as described in previous research (Hydén, 2008; McNeill, 1992; Merleau-Ponty, 1964; Roth, 2001). These body expressions, the natural gestures, are known to be of importance in connection with oral speech, and in particular, with storytelling (Young, 2000, 2011). One student teacher's storytelling is shared below. I will examine and analyze this as a representative example of the other seminars. All names have been anonymized and any reference to school names has been removed.

\section{The Taleworld of Becoming}

The presentation of the results follows the narrative structure of the student teacher Clara's storytelling. In my attempts to grasp the lived experience of learning professional ways of being during the internship, as expressed through her oral storytelling, I analyze the events in the taleworld intertwined with the embodied storytelling. The focus on how the situated storytelling reveals complexities in teaching challenges the prevailing neoliberal view on teachers' work. The transcribed video recordings have been organized in a table, with the spoken words to the left, the transcription of the narrators' gestures, postures, and facial gestures in the center, and images of gestures to the right. In the left-hand column, the spoken words are underscored to mark with which words the gestures unfold. The number assigned to each tuple represents the analyzed storytelling sequence in chronological order.

\section{Becoming Professional}

Clara describes a pedagogical situation where there is a new pupil in the class who is very shy and who neither answers questions in the class, nor turns to the supervising teacher or student teacher. ${ }^{2}$ Clara then moves from describing the pedagogical situation, in the storyrealm, to visualizing her lived experiences of pedagogical action. From a phenomenological perspective on storytelling, Clara starts to embody events in the taleworld (see Tuple 4).

\begin{tabular}{|c|c|c|c|}
\hline \multicolumn{4}{|c|}{ Table 1} \\
\hline 4 & $\begin{array}{l}\text { She had a hard time } \\
\text { getting started with all the } \\
\text { tasks so I used to go up to } \\
\text { her and: }\end{array}$ & $\begin{array}{l}\text { Iconic gesture where the right-hand } \\
\text { thumb and fingers are brought together } \\
\text { and a movement is hinted that indicates } \\
\text { writing }\end{array}$ & \\
\hline 5 & PAUSE $2.0 \mathrm{~s}$ & & \\
\hline 6 & $\begin{array}{l}\text { "It can be difficult to get } \\
\text { started" }\end{array}$ & $\begin{array}{l}\text { Speaks from a character view as the } \\
\text { student teacher in the story }\end{array}$ & \\
\hline 7 & $\begin{array}{l}\text { "Usually I } \underline{\text { also }} \text { have } \\
\text { difficulty in getting } \\
\text { started" }\end{array}$ & $\begin{array}{l}\text { Moving her head very short, a little } \\
\text { sideways like a beat }\end{array}$ & \\
\hline 8 & $\begin{array}{l}\text { "If that happens I usually } \\
\text { do this and that" and so on }\end{array}$ & $\begin{array}{l}\text { Both hands move in circles in front of } \\
\text { the body }\end{array}$ & 6 \\
\hline 9 & $\begin{array}{l}\text { Then she sat and looked a } \\
\text { little and sometimes } \\
\text { smiled a little }\end{array}$ & $\begin{array}{l}\text { Iconic posture "looking upwards" in } \\
\text { character view as the pupil }\end{array}$ & $\begin{array}{l}\text { Spoken: } \underline{\text { She had a hard }} \\
\text { time getting started }\end{array}$ \\
\hline
\end{tabular}

\footnotetext{
${ }^{2}$ This part of Clara's story, Tuples 1 to 3 , is not shown in the table.
} 


\begin{tabular}{|l|l|l|l|}
\hline 10 & $\begin{array}{l}\text { Then she was left alone } \\
\text { for a while }\end{array}$ & Container gesture ${ }^{3}$ to the left \\
\hline 11 & $\begin{array}{l}\text { Then she started to write a } \\
\text { little anyway, and so on }\end{array}$ & $\begin{array}{l}\text { Iconic gesture, in a character view as the } \\
\text { pupil, with the right hand grasping a pen }\end{array}$ & \\
\hline
\end{tabular}

After the short pause (5), Clara enters the taleworld with a quote from herself as a character in the story (6 and 7), and continues by saying: "I usually do this and that" (8) with a rotating gesture with both hands interwoven with the words to emphasize that she suggested different ways of getting started. In my interpretation, Clara explores her experiences of pedagogically seeing the pupil. According to Saevi and Foran (2012), pedagogically seeing is not the same as having "knowledge about students, pedagogy, or teaching" but is more as "sensing and understanding" the students (p. 60). Thus Clara has experienced what it is like to use her own writing experiences as a way to teach by example, and, at the same time, relate to and recognize the pupil's difficulties in getting started.

Clara continues and she shifts to the girl's perspective again (9), turning her face, acting as the pupil, slightly upwards as if she were looking at the student teacher-in this case herself - as a character in the storytelling. This very short posture illustrates, from within the time and space of the taleworld, an embodied posture of pedagogically seeing as a way of "relating and existing" in the classroom (Saevi \& Foran, 2012, p. 60). Clara relates and acts intuitively in making the decision to let the pupil be for a while (10): her storytelling reveals experiences of a tactful way of teaching that is overlooked in the neoliberal view on teaching as managing, which narrows teachers' professional duties down to conveying official school knowledge to pupils and assessing their performances (Nilsson-Lindström \& Beach, 2015). Clara's lived experiences show significance for future teachers: her embodied professional way of being exemplifies when it is educationally desirable for restrained teaching (Hopmann, 2007).

Clara attempts to get in contact with the shy pupil; to get her to open up. She talks to her at breaks and after a lesson. Then, suddenly something happens when they sit together to have a meal. Clara tells the pupil personal anecdotes about failures and funny incidents where everything went wrong and suddenly the girl starts to talk (see Table 2).

\begin{tabular}{|l|l|l|l|}
\hline \multicolumn{2}{|l|}{ Table 2 } & $\begin{array}{l}\text { And (told) about once } \\
\text { when she had }\end{array}$ & Smiling (12-16) \\
\hline 12 & $\begin{array}{l}\text { done some exercise that } \\
\text { had gone totally wrong and }\end{array}$ & $\begin{array}{l}\text { Both hands in front of the body } \\
\text { like that... }\end{array}$ & $\begin{array}{l}\text { gesture with an audible beat, } \\
\text { right after the spoken word } \\
\text { "that" with hands on the legs }\end{array}$ \\
\hline 14 & $\begin{array}{l}\text { It was not a long story but } \\
\text { never the less it was. }\end{array}$ & $\begin{array}{l}\text { Starts forming a container } \\
\text { gesture }\end{array}$ & \\
\hline
\end{tabular}

\footnotetext{
${ }^{3}$ A container gesture is metaphoric, i.e. representing "abstract ideas as if they were concrete acts and objects" (Young, 2011). This particular gesture is usually performed with the two palms facing each other as framing a content or, as in Clara's storytelling (Tuple 24), with an upward-facing palm slightly cupped, as holding or offering, what the talk is about. McNeill (1992) refers to these kinds of container gestures as cup gestures.
} 


\begin{tabular}{|l|l|l|l|}
\hline 15 & $\begin{array}{l}\text { She talked and she told a } \\
\text { story }\end{array}$ & Container gesture & $\begin{array}{l}\text { Container gesture, iconic gesture } \\
\text { moving the head a little bit } \\
\text { forward as a beat on the word } \\
\text { "me" }\end{array}$ \\
\hline 16 & and she looked at me & Spoken: And she looked at $m e$ \\
\hline
\end{tabular}

This is the turning point of the story and is embodied visually as it is told by the student teacher. Clara tells this event emotionally and smilingly $(12-16)$ with audible and visual beats $(13,16)$, which reflects a teacher's satisfaction in forming a pedagogical relation with a pupil. Clara encourages the pupil to tell stories, explicitly using her own storytelling as an example. She offers a phenomenological possibility to her pupil to participate in her story via the pupil's own lived experience. Through her storytelling, Clara is what Heidegger (2010) describes as "leaping ahead" (p. 119) in her concern for the pupil: she pertains to the pupil's existencecaring for the pupil's present self, including the pupil's future self, and offering her possibilities to grow as a human being. Clara performs a container gesture (14-15) as she is considering this important event, when she experienced a teacher's satisfaction, as something concrete.

The storytelling continues metaphorically (16), As an object from her external perspective, Clara uses the rest of her body as an iconic representation of her pupil's character looking up at the student teacher (herself as a character in the story) from an internal perspective. This double embodiment produces empathy and transformation when shifting character perspective (Young, 2000). Clara's storytelling communicates a strong "I see you" that is mutually shared in this moment. It is in moments like these-when she is both being herself and being her pupil - that the body of the student teacher makes itself available for transformation in both the taleworld and in the storytelling occasion. Clara seems to have experienced a professional way of being that rests on a reciprocal relationship: when sharing anecdotes of previous school failures the student teacher and the pupil each devote themselves to the same thing in common. This authentic way of being a teacher, as being-with the pupil (Donnelly, 1999), stands in sharp contrast to the neoliberal perspective on teaching, which is forgetful of being and steers teachers towards the instrumental managing of "objective" performances.

Clara reasons about the progress the pupil made in class after the moment of shared storytelling (see Table 3). 


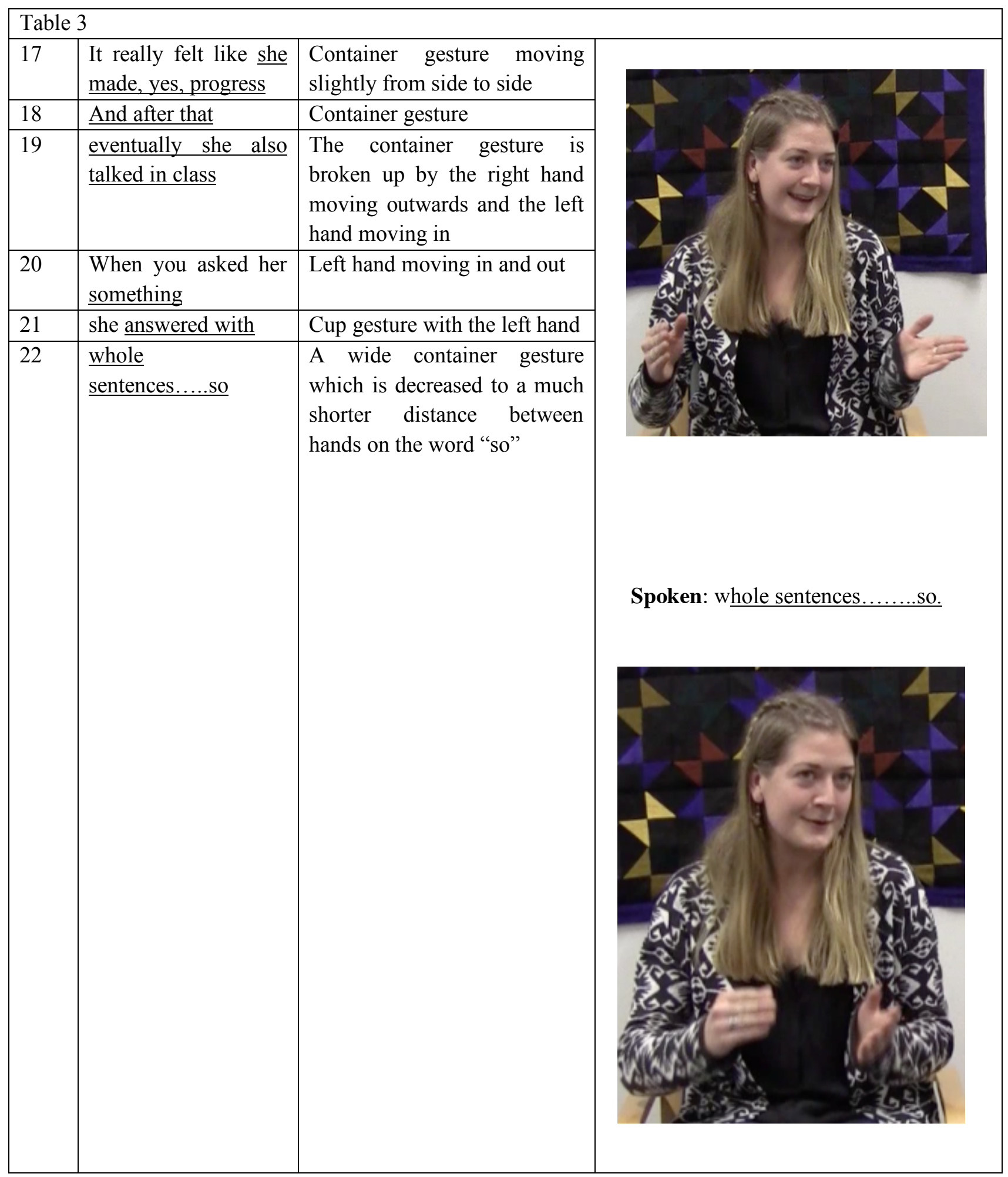

Clara uses more metaphoric gestures (17-22) in describing the pupil's progress than she did when recounting events in the taleworld (12-16), where she used more iconic gestures. The metaphoric gesture of hands turning over each other (19) are interwoven with spoken words about how the pupil's talk is now flowing like a stream in the classroom. The questions posed to the pupil in class are expressed with a cupping gesture (20) and a movement with one hand is a visualization of her answer (21). Finally, Clara smiles with great joy (17-22) and shares what she experiences according to the anecdote as the girl's success in answering questions 
with whole sentences, using a wide container gesture for the length of the sentences of the pupil's answer (22).

\section{Complexities of Teaching}

Clara's account is a relatable and recognizable "success story" (Ochs \& Capps, 2001, p. 217). It has a positive ending that is closely connected to the initial problem framed at the beginning of the story: a very shy and quiet pupil make progress and becomes more engaged in class activities with help from the student teacher. Although the narrative turning point is emotional and I feel empathy for the student teacher and for the pupil, in this moment I realized that there is no punctum, a detail that disturbs my pre-conceived understanding of the story and storytelling that makes me acknowledge the ambiguity of a lived experience in Clara's anecdote.

Suddenly, something happens that is seemingly not connected to the unfolded events of the narrative: Clara reduces the distance between her hands in a last gesture (22). She dramatically lowers her hands with only one word; the confirming "so." This gesture punctures me, it pricks me, it interrupts the interpretation of this story. What does this mean?

When I shut my eyes and reflect on the storytelling occasion, this gesture comes to my mind. I interpret it as suggesting that, even when telling the story and performing the gesture of success, the student teacher is already bothered by the complexities and ambiguities in teaching: measurability of performance or the process of personal growth (Biesta, 2009). Yes, the girl did much better, but not well enough, according to the supervising teacher. When Clara's story is shared intercorporeally, it becomes an emotional, embodied, and concrete lived experience, making it possible to reflect on as a teacher. The student teacher's story about the pupil's storytelling allows for another professional way of seeing this pupil's progress other than as a performance that can be measured as an acquisition of knowledge. As a teacher educator, I am forced to think about the ambiguity in teaching and the experience of pedagogical tact (van Manen, 1991, 2015): what is the right thing to do for this particular pupil in this specific situation? I interpret Clara's gesture, which is clearly connected to the spoken words but takes place afterwards in silence, as a correction of the length of the sentence. The length of the sentence is, so to speak, under consideration. The gesture is already linked to what she is feeling and thinking about, and what she is going to tell us next.

After the positive ending to the story, accompanied by the decreasing gesture, there is a shift and Clara starts to talk about the supervising teacher and how she is worried about the pupil. Regardless of the progress the student teacher experienced, the teacher is not satisfied with the pupil's academic progress, and she says that she cannot make any assessment due to the lack of performance. From a neoliberal and instrumental practice, it is essentially the pupils' measurable results that counts (cf. Biesta, 2009). The supervising teacher explains, according to Clara, that the girl will not achieve the goals for the course. My interpretation concerns the student teacher's ambiguous experience of being both a teacher who is concerned with the pupil's failure in performing something measurable in relation to standards, and being a teacher who sees the pupil's involvement in class as progress (see Table 4). 


\begin{tabular}{|l|l|l|l|}
\hline \multicolumn{2}{|l|}{ Table 4} \\
\hline 23 & $\begin{array}{l}\text { The teacher was } \\
\text { really concerned } \\
\text { about }\end{array}$ & $\begin{array}{l}\text { a cup gesture with the left hand in a } \\
\text { low position and the right hand above } \\
\text { becomes a container gesture }\end{array}$ \\
\hline 24 & $\underline{\text { what to do }}$ & Two cup gestures \\
\hline 25 & $\begin{array}{l}\text { to get this pupil } \\
\text { to show what she } \\
\text { can do }\end{array}$ & $\begin{array}{l}\text { deictic gesture with right hand as a cup } \\
\text { gesture }\end{array}$ & \\
\hline
\end{tabular}

Clara holds the teacher's concern, metaphorically by the container gesture, which is then turned to the listeners, and she offers the listeners two cupping gestures (24-25), which are metaphors for holding, offering something, in this case questions and speculations like: "How should one act in this case? What should one do?" In my interpretation, these demanding questions of pedagogical tact (van Manen, 1991, 2015), which Clara implies, stem from her embodied exploring of the taleworld through her anecdote about the internship. Simultaneously, the storytelling offer us listeners a possibility to reflect upon the ambiguous, emerging irrational, and emotional experience relating to Clara being a teacher in that moment. Clara does not give us her opinion; instead she shows us her lived experience. Obviously, the student teacher's reflection opens the way for a discussion about a professional way of being within the praxis seminar, where an answer involving subject matter knowledge and vocational practical skills cannot be considered sufficient. Is there an answer to Clara's concern, the wellbeing of the pupil in light of the Swedish government's push for evidence-based teaching practices? CochranSmith (2005) is clear: "Even on that grand day when all the evidence is in, we will still need to make decisions based in part on values, moral principles, priorities, available resources, tradeoffs, and commitments" (p. 9). The student teacher's emotionality embodies a lived pedagogical moment, and she uses her anecdote, accompanied with natural gestures and postures, to convey meaning to the lived experience of being a teacher. Clara's narration displays an embodied interaction with a pedagogical situation in relation to the pupil as being in the time and space of the story. In the shrinking gesture, Clara embodies the ambiguity that exists, the tension constituted by the relationship between pupils' becoming and being measured, and seen through the neoliberal lens, as already being. Clara's account reveals the tensions between her embodied experience of pedagogical sensitivity to know what is the best to do for this pupil and the teacher's choice of pedagogical action according to the pupil's performance in relation to entrenched scholastic standards. Clara's anecdote illustrates a complex educational reality with ambiguities, emotions, and relations, and it unfolds as a professional way of being a teacher that is not recognized in neoliberal times. 


\section{Conclusion}

Oral storytelling can support the process of revealing student teacher's lived experiences of learning professional ways of being a teacher that is compliant with the complexities and ambiguities that characterize teaching. Unfortunately, this dimension is often overlooked in Swedish teacher education due to pervasive neoliberal reforms of the curriculum designed to prepare future teachers. Paramount for student teachers is to have the opportunity to explore their experiences as they develop their professional ways of being, and Dall'Alba (2009) calls for an ontological turn in teacher education to explore the phenomenon of being and becoming a teacher.

The student teachers involved in the praxis seminar were asked to tell stories about something that profoundly impacted their internship. The stories they shared were about something that was significant from all the other experiences in the everyday mode of being a teacher (Ochs \& Capps, 2001). Clara's story is a touching experience, not based on theoretical assumptions or neoliberal opinions, but due to students' lived experiences. Clara's storytelling embodies care, and her telling reveals a recognizable pedagogical element in her storytelling, making it possible to reflect upon particularities as universal for teachers. As van Manen (1991) expresses it: "we might say that telling anecdotes is a form of everyday theorizing" (p. 204). From the perspective of the storytelling as interwoven, the storyteller's lived body, with its arbitrary and situational aspects of temporal, spatial, emotional and relational perspectives, provides opportunities to express and make sense of lived teaching experiences not only for the listeners but also for the storytellers themselves.

There is a concern, an ambiguous and embodied lived experience of the professional being, that is the starting point for the student teachers' narratives in this study. It is the oral storytelling that makes it possible to share these complex lived experiences from a personal embodied perspective. Clara's anecdote reveals professional ways of being that rests on examples of pedagogically seeing (Savie \& Foran, 2012), restrained teaching (Hopmann, 2007), reciprocal relationship, and how to act with pedagogical tact and sensitivity (van Manen, 1991, 2015). Additionally, Clara shows that student teachers' embodied storytelling potentially possesses the punctum required to open up reflections of everyday teaching to the ambiguities in being and becoming a teacher that cannot be captured in neoliberal approaches. Stories of significant moments offer a concrete and possible way to explore and raise questions about becoming a teacher for teacher educators, and allow beginning teachers a way to grasp the difficult educational reality, which Bollnow (see Koerrenz, 2017) describes as emotional, irrational, and disruptive in the everydayness of teaching. Storytelling opens up educational discourse to what is possible in countering and deconstructing the infiltration of neoliberalism in public school teaching, and the narrow teacher training paradigm in Sweden. The practice of storytelling as part of teacher education process for beginning teachers is a way to embody their lived experiences in the transformation to becoming a teacher.

\section{References}

Andrews, M., Squire, C. \& Tamboukou, M. (Ed.) (2008). Doing narrative research. Los Angeles: SAGE.

Apple, M. W. (2001). Markets, standards, teaching, and teacher education. Journal of Teacher Education, 52(2), 182-196. 
Bamberg, M., \& Demuth, C. (2016). Narrative inquiry: An interview with Michael Bamberg. Europe's Journal of Psychology, 12(1), 14-28.

Beach, D. \& Bagley, C-A. (2012). The weakening role of education studies and the retraditionalisation of Swedish teacher education. Oxford Review of Education, 38(3), 287-303.

Blake, R.W. \& Blake, B.E. (red.) (2012). Becoming a teacher: Using narrative as reflective practice: A cross-disciplinary approach. New York: Peter Lang.

Biesta, G.J.J. (2009). Good education in an age of measurement: on the need to reconnect with the question of purpose in education. Educational Assessment, Evaluation and Accountability, 21(1), 33-46.

Bruner, J.S. (1986). Actual minds, possible worlds. Cambridge, Mass.: Harvard Univ. Press

Cochran-Smith, M. (2005). The new teacher education: For better or for worse. Educational Researcher, 34(7), 3-17.

Dall'Alba, G. (2009). Learning professional ways of being: Ambiguities of becoming. Educational Philosophy and Theory, 41(1), 34-45.

Donnelly, J.F. (1999). Schooling Heidegger: On being in teaching. Teaching and Teacher Education, 15(8), 933-949.

Dovemark, M., \& Holm, A-S. (2017). The performative culture in Swedish schools and how teachers cope with it. In Borgnakke, K., Dovemark, M., \& da Silva, S.M. (Eds.): The postmodern professional. Contemporary learning practices, dilemmas and perspectives (pp. 33-52). London: Tufnell Press.

Garvis, S. (2015). Narrative constellations [Electronic recourse]: Exploring lived experience in education. Rotterdam: Sense Publishers.

Goodson, I. (2010). Narrative learning. London: Routledge.

Gustavsson, S. (2008). Motstånd och mening: innebörd i blivande lärares seminariesamtal. Diss. Göteborgs universitet. Göteborg.

Göteborgs universitet. (2018). Kursplan. Verksamhetsförlagd utbildning 1 för lärare åk 4-6, 7,5 hp. Göteborg: Göteborgs universitet, Institutionen för didaktik och pedagogisk profession.

Heidegger, M. (2010). Being and time. Albany: State University of New York Press.

Hopmann, S. (2007). Restrained teaching: the common core of Didaktik. European Educational Research Journal, 6(2), 109-124.

Hydén, L. (2008). Bodies, embodiment and stories. In Andrews, M., Squire, C. \& Tamboukou, M. (Eds.), Doing narrative research (pp. 126-141). Thousand Oaks, California: Sage. 
Karlsson, R. (2013). Emotional identification with teacher identities in student teachers' narrative interaction. European Journal of Teacher Education, 36, 133-146.

Koerrenz, R. (2017). Existentialism and education - an introduction to Otto Friedrich Bollnow. Springer International Publish.

Lindqvist, P., Nordänger, U-K. \& Carlsson, R. (2014) Teacher Attrition the First Five Years A Multifaceted Image. Teaching and Teacher Education, 40(4), 94-103.

Luehmann, A.L. (2007). Identity development as a lens to science teacher preparation. Science Education, 91, 822-839.

McNeill, D. (1992). Hand and mind: what gestures reveal about thought. Chicago: University of Chicago Press.

Merleau-Ponty, M. (1964). The primacy of perception Chicago: Northwestern University Press.

Merleau-Ponty, M. (1968). The visible and the invisible Evanston, IL: Northwestern University Press.

Nilsson-Lindström, M \& Beach, D. (2015). Changes in teacher education in Sweden in the neo-liberal education age: Toward an occupation in itself or a profession for itself? Education Inquiry, 6(3), 241-258.

Nordänger, U-K. \& Lindqvist, P. (2015). Lärares förväntningar på yrket - bilder av handlingsfrihet 1993-2013. Pedagogisk forskning $i$ Sverige 20. (3-4), 195-220.

Ochs, E. \& Capps, L. (2001). Living narrative: Creating lives in everyday storytelling. Boston: Harvard University Press.

Player-Koro, C. (2012). Reproducing traditional discourses of teaching and learning mathematics: studies of mathematics and ICT in teaching and teacher education. Diss. Göteborg : Göteborgs universitet

Roth, W-M. (2001). Gestures: Their role in teaching and learning. Review of Educational Research, 71(3), 365-392.

Saevi, T. \& Foran, A. (2012). Seeing pedagogically, telling phenomenologically: Addressing the profound complexity of education. Phenomenology \& Practice, 3(10), 50-64.

SOU 2008:109. En hållbar lärarutbildning: Betänkande av Utredningen om en ny lärarutbildning. Stockholm: Utbildningsdepartementet

van Manen, M. (1991). The tact of teaching: the meaning of pedagogical thoughtfulness Albany, N.Y.: State University of New York Press.

van Manen, M. (2014). Phenomenology of practice: Meaning-given methods in phenomenological research and writing U.S.A: Left Coast Press. 
van Manen, M. (2015). Pedagogical tact: knowing what to do when you don't know what to do. Walnut Creek: Left Coast Press.

Young, K. (1987). Taleworlds and storyrealms: The Phenomenology of Narrative. Dordrecht: Martinus Nijhoff Publishers.

Young, K. (2011). Gestures, Intercorporeity, and the Fate of Phenomenology. Folklore Journal of American Folklore, 124(492), 55-87.

Young, K. (2000). Gestures and the phenomenology of emotion. Narrative Semiotica, $131(1 / 2), 79-112$

Yuan, R \& Lee, I. (2016). I need to be strong and competent: A narrative inquiry of a student teacher's emotions and identities in teaching practicum. Teachers and Teaching, 22(7), 819-841.

Zeichner, K. (2010). Competition, economic rationalization, increased surveillance, and attacks on diversity: neo-liberalism and the transformation of teacher education in the US. Teaching and Teacher Education, 26(8), 1544-1555. 